\title{
MJMR THE EFFECTS OF EARLY EDUCATIONAL INTERVENTION ON PATIENTS WITH ACUTE CORONARY SYNDROME (ACS): A REVIEW
}

\author{
Harlinna binti Abu, Salizar binti Mohamed Ludin, Siti Noorkhairina binti Sowtali, Salizar \\ binti Mohamed Ludin* \\ Kuliyyah of Nursing, International Islamic University Malaysia, Bandar Indera Mahkota Campus, Kuantan, \\ Pahang, Malaysia \\ *Corresponding Author's Email: : msalizar@iium.edu.my
}

\begin{abstract}
Participation in cardiac rehabilitation program (CRP) had proven to promote a healthy lifestyle to improve quality of life after cardiac event. Early educational intervention is very important to prepare the patient before discharged home due to the poor enrolment in the CRP. The aims of this review are to describe the early educational interventions offered to the patients with ACS and to review its effectiveness. A literature review was conducted by analyzing related research studies published since 2009 to 2018 . There were eight studies included in this review. Alternative approaches need to be considered for cardiac rehabilitation, where appropriate programs for patients that suits with the patients' needs especially while the patients are still in the hospital. The early educational intervention that inculcates the self-efficacy enhancement should be considered to guide the patients to manage themselves at home and lead a healthy lifestyle to prevent the recurrence of the disease.
\end{abstract}

\section{Keywords: Inpatient Education, Early Education, Acute Coronary Syndrome}

\section{INTRODUCTION}

According to Malaysia National Cardiovascular Disease-Acute Coronary Syndrome (NCVD-ACS) Registry 2011-2013, ACS caused in-hospital mortality rate of $7.6 \%$ and 30 days-mortality rate of $9 \%$ out of 14,763 patients admitted. The mean age was 59 years (SD 12), with $24 \%$ under the age of 50 years and $76 \%$ of patients were male (National Cardiovascular Disease Database (NCVD), 2013). Surprisingly, $65.2 \%$ of the patients admitted already had a history of myocardial infarction. There were $12 \%$ of them readmitted and diagnosed as STEMI, 24\% as NSTEMI and 29.2\% readmitted due to unstable angina (NCVD, 2013). Thus, rehabilitation as a secondary prevention should be focused on these patients in order to prevent the recurrent of myocardial infarction and further deteriorating the health status of the patients.

CRP following a cardiovascular event is a Class I recommendation highlighted by the European Society of Cardiology, the American Heart Association, and the American College of Cardiology (Galve et al., 2014). While in Malaysia, it is recommended that strategies for secondary prevention for post STEMI which are smoking cessation and exercise both have level of evidence B (data derived from a single randomized clinical trial or large nonrandomized studies) and grade of recommendation of I (conditions for which there is evidence and/or general agreement that a given procedure/therapy is beneficial, useful and/or effective) (Malaysian Ministry of Health, 2014).

Although many studies proved the benefits of CRP (Oldridge, Höfer, \& Mcgee, 2012; Dunlay, Pack, Thomas, Killian, \& Roger, 2014; Chernomordik et al., 2017 and Dunlay et al., 2014), unfortunately, it remains considerably underutilized mainly because of referral problems and poor participation (Engen-Verheul, H., De-Vries, H., Kemps, H., Kraaijenhagen, R., De Keizer, N., Peek, N. 2013; Mampuya, 2012 and Turk-Adawi, K., Oldridge, N.B., Tarima, S.S., Stason, W.B., Shepard, D.S. 2014). (Beauchamp et al. 2013 and Lemstra et al. 2013) reported less than half of the participants completed the CRP. While, in Malaysia, the status of the attendance and referral to the CRP is underreported and unclear.

Poor enrollment and attendance makes the Phase 1 of CRP or inpatient CRP is very crucial as the participants is still in the hospital and the early educational intervention is possible. However, the shorter hospital stay with modern cardiac treatment makes it difficult to conduct formal inpatient early educational program. 
Thus, Phase I are mostly limited to early mobilization to make self-care possible by discharge, and brief counselling about the nature of the illness, the treatment, risk factors management and follow-up planning. This literature review is focusing on the inpatient educational intervention offered to the patients with Acute Coronary Syndrome (ACS) and the outcomes of the intervention.

\section{METHODOLOGY}

\section{Literature search strategies}

The aims of this literature review are to analyse, summarize, and synthesize the nature of the early educational interventions offered to the patients with Acute Coronary Syndrome and the outcome of the interventions. The literature review search process is guided by specific objectives.

\section{Objective of literature review}

1. To describe the early educational interventions offered to the patients with ACS

2. To examine the outcomes after the early patient education intervention on patients with ACS

\section{Search strategies}

Four main online searched databases were used for the literature search; EBSCO Host Database, CINAHL, PubMed, and Scopus. The search strategy incorporated three concepts: a) acute coronary syndrome (ACS) and myocardial infarction (MI) using the "OR/AND" operator, b) intervention combining early education, inpatient education, patient education, cardiac rehabilitation with the "OR/AND" operator and c) outcomes of interest combining behaviour change, lifestyle change, physical activity, physiological outcomes with operator "OR/AND".

\section{Inclusion and exclusion criteria}

The inclusion criteria for in this literature search includes; full-text article, published from 2009 to 2018, in English language, experimental, prospective or observational study design, population of the study is coronary heart disease, acute coronary syndrome, and myocardial infarction. Meanwhile, the exclusion criteria include; the population studied is chronic heart failure patients, exploratory qualitative study, homebased intervention, outpatient intervention and noneducational intervention i.e. exercise training. Initially, there were 1,088 articles identified during the search process, based on title screening. However, in the final stage only eight articles are included for further review based on The Joanna Briggs Institute (JBI) Critical Appraisal Checklist for Cohort studies, JBI Critical Appraisal Checklist for quasi-experimental studies and JBI Critical Appraisal Checklist for randomized control trial studies.

\section{RESULTS}

There were eight studies included in this review from the year 2010 to 2017 (Table 1). Four studies were from European countries, which were from German (Meng et al., 2014), Canada (Harbman, 2014), Switzerland (Weibel, Massarotto, Hediger, \& Mahrer-imhof, 2014), and United Kingdom (Lau-Walker, Landy, \& Murrells, 2016) (Table 1). Two of the studies were from Turkey (Irmak \& Fesci, 2010 and Uysal \& Özcan, 2012). There were another two studies from South East Asia which were from Thailand (Vibulchai, Thanasilp, \& Preechawong, 2016) and Malaysia (Anchah et al., 2017) (Table 1). There are three randomized control trial study (Uysal \& Özcan, 2012; Vibulchai et al., 2016 and Weibel et al., 2014), three quasi-experimental (Anchah et al., 2017; Irmak \& Fesci, 2010 and Meng et al., 2014) and two cohort prospective study (Harbman, 2014 and Lau-Walker et al., 2016) (Table 1).

Table 1: The early educational interventions to ACS patients

\begin{tabular}{|l|l|l|l|l|l|}
\hline $\begin{array}{l}\text { Author/ Year/ } \\
\text { Country }\end{array}$ & Participants & $\begin{array}{l}\text { Research } \\
\text { design }\end{array}$ & Intervention & $\begin{array}{l}\text { Control } \\
\text { based }\end{array}$ \\
\hline Uysal \& Özcan, & 90 AMI patients & $\begin{array}{l}\text { Randomized } \\
\text { control trial }\end{array}$ & $\begin{array}{l}\text { Patients were individually } \\
\text { trained on the fifth to seventh } \\
\text { days before discharge for an } \\
\text { hour. Thentelephone counselling } \\
\text { regarding information on } \\
\text { measures for decreasing } \\
\text { cardiovascular risks at the } 4^{\text {th }} \\
\text { and } 8^{\text {th }} \\
\text { conducted after discharge were }\end{array}$ & $\begin{array}{l}\text { A home training } \\
\text { kit given to } \\
\text { participants. No } \\
\text { telephone } \\
\text { counselling and } \\
\text { training given. }\end{array}$ & Not mentioned \\
\hline
\end{tabular}




\begin{tabular}{|c|c|c|c|c|c|c|}
\hline $\begin{array}{l}\text { Vibulchai, } \\
\text { Thanasilp, \& } \\
\text { Preechawong } \\
2016 \\
\text { Thailand }\end{array}$ & 66 CAD patients & $\begin{array}{l}\text { Randomized } \\
\text { control trial }\end{array}$ & $\begin{array}{l}\text { Self-efficacy enhancement } \\
\text { program for cardiac } \\
\text { rehabilitation (SEPCR) - three } \\
\text { individualized in -hospital } \\
\text { education sessions and three } \\
\text { weekly sessions of telephone } \\
\text { counselling }\end{array}$ & $\begin{array}{l}\text { Two sessions of } \\
\text { CR during } \\
\text { hospitalization }\end{array}$ & $\begin{array}{l}\text { Self-efficacy } \\
\text { theory }\end{array}$ & Nurse \\
\hline $\begin{array}{l}\text { Weibel, } \\
\text { Massarotto, } \\
\text { Hediger, \& } \\
\text { Mahrer-imhof } \\
2014 \\
\text { Switzerland }\end{array}$ & 40 ACS patients & $\begin{array}{l}\text { Pilot } \\
\text { randomized } \\
\text { control trial }\end{array}$ & $\begin{array}{l}\text { Two interventions added to the } \\
\text { standard care. First intervention } \\
\text { is the assessment using Cardiac } \\
\text { Patient Learning Needs } \\
\text { Inventory (CPLNI) and } \\
\text { education given based on the } \\
\text { needs assessed. Second } \\
\text { intervention was educational } \\
\text { intervention on the day before } \\
\text { discharge regarding individual } \\
\text { risk factors, current cardiac } \\
\text { medication and personal disease } \\
\text { management barriers and } \\
\text { facilitators. }\end{array}$ & $\begin{array}{l}\text { Information given } \\
\text { to patients by } \\
\text { physician on daily } \\
\text { rounds and } \\
\text { information } \\
\text { booklet. }\end{array}$ & $\begin{array}{l}\text { Self-efficacy } \\
\text { theory }\end{array}$ & Nurse \\
\hline $\begin{array}{l}\text { Irmak \& Fesci } \\
2010 \\
\text { Turkey }\end{array}$ & 36 AMI patients & $\begin{array}{l}\text { One-group } \\
\text { pretest-posttest } \\
\text { quasi } \\
\text { experimental } \\
\text { design }\end{array}$ & $\begin{array}{l}\text { Six individual education } \\
\text { sessions initiated in the hospital } \\
\text { on the third day after MI and } \\
\text { continued after discharge during } \\
\text { home visits and completed in } 3 \\
\text { days. }\end{array}$ & Not applicable & Not mentioned & Nurse \\
\hline $\begin{array}{l}\text { Anchah et al. } \\
2017 \\
\text { Malaysia }\end{array}$ & $\begin{array}{l}\text { 112 ACS } \\
\text { patients }\end{array}$ & $\begin{array}{l}\text { Quasi- } \\
\text { experimental }\end{array}$ & $\begin{array}{l}\text { Clinical pharmacy services } \\
\text { added to the standard phase I } \\
\text { CRP protocol with intensive } \\
\text { drug counselling sessions, } \\
\text { medication adherence, and basic } \\
\text { knowledge on managing their } \\
\text { angina include: lifestyle } \\
\text { modifications and } \\
\text { pharmacological treat ments to } \\
\text { reduce cardiovascular risks }\end{array}$ & $\begin{array}{l}\text { Usual care, not } \\
\text { attending CRP. }\end{array}$ & Not mentioned & Pharmacists \\
\hline $\begin{array}{l}\text { Meng et al. } \\
2013 \\
\text { German }\end{array}$ & $\begin{array}{l}434 \mathrm{CHD} \\
\text { patients }\end{array}$ & $\begin{array}{l}\text { Quasi- } \\
\text { experimental, } \\
\text { sequential } \\
\text { cohort design } \\
\text { study }\end{array}$ & $\begin{array}{l}\text { Patient-oriented program } \\
\text { 'Curriculum Coronary Heart } \\
\text { Disease' } \\
5 \text { sessions of } 45 \mathrm{~min} \text { each } \\
\text { in small groups. }\end{array}$ & $\begin{array}{l}\text { Lecture based } \\
\text { education }\end{array}$ & $\begin{array}{l}\text { Health Action } \\
\text { Process } \\
\text { Approach }\end{array}$ & $\begin{array}{l}\text { Physician } \\
\text { Psychologist } \\
\text { Physiotherapist }\end{array}$ \\
\hline $\begin{array}{l}\text { Harbman } \\
2014 \\
\text { Canada }\end{array}$ & 65 AMI patients & $\begin{array}{l}\text { Prospective } \\
\text { cohort study }\end{array}$ & $\begin{array}{l}\text { Patient-centred comprehensive } \\
\text { cardiovascular assessments and } \\
\text { education, counselling and } \\
\text { treatment recommendations } \\
\text { related to heart attack recovery } \\
\text { and secondary prevention care } \\
\text { before discharge from hospital } \\
\text { and on e week, two weeks, six }\end{array}$ & $\begin{array}{l}\text { Nutritional } \\
\text { counselling and } \\
\text { discharge teaching } \\
\text { by registered } \\
\text { nurse. }\end{array}$ & Not mentioned & Nurse \\
\hline $\begin{array}{l}\text { Lau-Walker, } \\
\text { Landy \& Murrells } \\
2016 \\
\text { United Kingdom }\end{array}$ & 74 AMI patients & $\begin{array}{l}\text { Longitudinal } \\
\text { survey }\end{array}$ & $\begin{array}{l}\text { The Personalised Patient } \\
\text { Educational Protocol (PPEP) } \\
\text { was designed to facilitate } \\
\text { systematic nurse -patient } \\
\text { interaction to clarify patients' } \\
\text { interpretation of health } \\
\text { promotion advice and } \\
\text { strengthen their capacity to } \\
\text { manage suggested health } \\
\text { behaviour and lifestyle changes. }\end{array}$ & Not applicable & Not mentioned & Nurses \\
\hline
\end{tabular}




\section{Target population}

The target population for the intervention were patients with acute coronary syndrome that includes myocardial infarction, coronary heart disease or coronary artery disease. The number of participants enrolled in the studies ranged from 36 to 434 participants in the quasi experimental and longitudinal studies, and 40 to 136 participants in the randomized control trial studies. The target population exclude patients with heart failure and post Coronary Artery Bypass Graft surgery.

\section{Setting}

To ensure the educational intervention is given as early as possible, all studies initiated the interventions in the ward itself. There were studies conducted in few sessions in the hospital before the participants were discharged home. The other four studies conducted the early educational intervention before discharge, and then the participants came back to the hospital for the rehabilitation sessions, and a study that continued the intervention at home by telephone counselling .

\section{Follow up duration}

The duration of follow up also plays an important role in measuring the effects of the intervention. Studies by Anchah et al. (2017) and Meng et al. (2014) had the longest duration measured which is up to one year. The other study measured the effects at 4 weeks (Vibulchai et al., 2016), 3 months (Harbman, 2014; Lau-Walker et al., 2016; Uysal \& Özcan, 2012) and 6 months (Irmak $\&$ Fesci, 2010).

\section{The early educational intervention}

\section{Nurse-led intervention}

The intervention was delivered mostly by nurses (Harbman, 2014; Irmak and Fesci, 2010; Lau-Walker et al., 2016; Uysal \& Özcan, 2012; Vibulchai et al., 2016 and Weibel et al., 2014), one study by pharmacists (Anchah et al., 2017) and another one study by multidisciplinary personnel include physiotherapy, physician and psychologist (Meng et al., 2014). All studies also an individually-targeted education except study done by (Meng et al. 2014) where the intervention delivered in a small group of participants.

\section{Theory-based intervention}

There were three studies that used theory-driven intervention. Two studies used Self-efficacy theory (Vibulchai et al., 2016 and Weibel et al., 2014). Vibulchai et al. (2016) designed the intervention based on Bandura self-efficacy to enhance self-efficacy for independent exercise and activities of daily living (ADL) performance using self-efficacy sources (i.e. enactive mastery experience, vicarious experience, verbal persuasion, and physiological and emotional states) and collaboration with a family member who provided support. While Weibel et al. (2014) used the goal of the intervention as improving patients' knowledge of their disease and treatment as well as strengthen patient's belief in their own capabilities to cope with the illness and plan for their future after discharge. (Meng et al., 2014) inculcate the theory of Health Action Process Approach as a guide to the intervention. (Meng et al. 2014) developed a patientoriented program called 'Curriculum Coronary Heart Disease', where there are five sessions of $45 \mathrm{~min}$ each in small groups delivered by multidisciplinary personnel, which were a physician, a psychologist and a physiotherapist as compared to the usual care where the participants were given a lecture-based education.

\section{Follow up duration}

The duration of follow up also plays an important role in measuring the effects of the intervention. Studies by (Anchah et al. 2017 and Meng et al. 2014) had the longest duration measured which is up to one year. The other study measured the effects at 4 weeks (Vibulchai et al., 2016), 3 months (Harbman, 2014; Lau-Walker et al., 2016 and Uysal \& Özcan, 2012) and 6 months (Irmak \& Fesci, 2010).

The outcomes of the early educational intervention during cardiac rehabilitation

There were many outcomes measuring the effectiveness of the educational interventions. However, in this study, the researcher will discuss on the significant positive outcomes from the educational intervention (Table 2). 


\begin{tabular}{|c|c|c|c|}
\hline $\begin{array}{l}\text { Author/ } \\
\text { Year/ } \\
\text { Country }\end{array}$ & Measurement & Measurement point & Main findings \\
\hline $\begin{array}{l}\text { Uysal \& } \\
\text { Özcan, } \\
2012 \\
\text { Turkey }\end{array}$ & $\begin{array}{l}\text { Clinical data } \\
\bullet \quad \text { BMI } \\
\text { - } \quad \text { Waist } \\
\text { circumference } \\
\text { - } \quad \text { Blood pressure } \\
\text { Lifestyle } \\
\bullet \quad \text { Smoking } \\
\text { - Physical activity } \\
\text { - Consume animal } \\
\quad \text { fat } \\
\text { Myocardial Infarction } \\
\text { Dimensional } \\
\text { Assessment Scale } \\
\text { (MIDAS) } \\
\text { SF-36 Quality of life }\end{array}$ & $\begin{array}{ll}\text { - } & \text { Before } \\
\text { intervention } \\
\text { - } 3 \text { months }\end{array}$ & $\begin{array}{l}\text { - A significant difference in the } \\
\text { intervention group in both the } \\
\text { MIDAS and the SF- } 36 \text { quality of } \\
\text { life scales' third month of } \\
\text { evaluations in comparison with } \\
\text { the baseline values }(\mathrm{P}<0.000) \\
\text { - Improvement was observed in } \\
\text { comparison with the control } \\
\text { group in terms of quitting } \\
\text { smoking, physical activity, body } \\
\text { mass index, waist circumference } \\
\text { A significant difference was } \\
\text { observed in the third month of } \\
\text { evaluation }\end{array}$ \\
\hline $\begin{array}{l}\text { Vibulchai, } \\
\text { Thanasilp, \& } \\
\text { Preechawong } \\
2016 \\
\text { Thailand }\end{array}$ & $\begin{array}{l}\text { Lifestyle } \\
\qquad \text { Smoking } \\
\text { - Physical activity } \\
\text { - Eating habit } \\
\text { The Duke Activity } \\
\text { Status Index } \\
\text { Maintain Function } \\
\text { subscale of the Cardiac } \\
\text { Self-efficacy Scale } \\
\text { (CSES) }\end{array}$ & $\begin{array}{l}\text { - } \text { Before discharge } \\
\text { - } 4 \text { weeks after } \\
\text { discharge }\end{array}$ & $\begin{array}{l}\text { Maintain function subscale of Cardiac } \\
\text { self-efficacy } \\
\text { - The experimental group exhibited a } \\
\text { significantly higher total self-efficacy } \\
\text { score than the control group } \\
\text { Functional status } \\
\text { - The experimental group exhibited a } \\
\text { significantly higher total functional } \\
\text { status score than the control group }\end{array}$ \\
\hline $\begin{array}{l}\text { Weibel, } \\
\text { Massarotto, } \\
\text { Hediger, \& } \\
\text { Mahrer- } \\
\text { imhof } \\
2014 \\
\text { Switzerland }\end{array}$ & $\begin{array}{l}\text { Lifestyle } \\
\qquad \quad \text { Smoking } \\
\text { Cardiac Self - efficacy } \\
\text { scale } \\
\text { Hospital Anxiety and } \\
\text { Depression Scale } \\
\text { Attendance to } \\
\text { rehabilitation }\end{array}$ & $\begin{array}{ll}\text { - } & \text { Before } \\
\text { intervention } \\
\text { - } & \text { Before discharge } \\
\text { - } & 3 \text { weeks } \\
& \text { telephone follow } \\
\text { up }\end{array}$ & $\begin{array}{l}\text { When controlling for anxiety and } \\
\text { depression, the intervention group } \\
\text { showed significant better self -efficacy } \\
\text { scores on the ability to control the } \\
\text { symptoms ( } p=0.034) \text {. } \\
\text { When controlling additionally for age, no } \\
\text { significant differences could be detected. } \\
\text { The attendance of a rehabilitation } \\
\text { programme was higher in the } \\
\text { intervention group. } \\
\text { The participants in the intervention group } \\
\text { reported high satisfaction with the early } \\
\text { education }\end{array}$ \\
\hline
\end{tabular}




\begin{tabular}{|c|c|c|c|}
\hline $\begin{array}{l}\text { Irmak \& } \\
\text { Fesci } \\
2010 \\
\text { Turkey }\end{array}$ & \begin{tabular}{|l} 
Lifestyle \\
- Smoking \\
- Eating habit \\
Drug thercise \\
compliance \\
Clinical measurement \\
- Blood pressure, \\
- BMI \\
- Lipid (total \\
cholesterol, \\
LDL, HDL and \\
triglycerides)
\end{tabular} & $\begin{array}{ll}\text { - } & \text { Before } \\
\text { intervention } \\
\text { - } & \text { 6months after } \\
\text { discharge }\end{array}$ & $\begin{array}{l}\text { Lifestyles } \\
\text { - There is significant difference in } \\
\text { smoking habit, caring food habit and } \\
\text { regular exercise habit before and after } \\
\text { the program } \\
\text { Risk factors measure } \\
\text { - There is significant difference in } \\
\text { blood pressure, BMI, and lipid before } \\
\text { and after the program }\end{array}$ \\
\hline $\begin{array}{l}\text { Anchah et al. } \\
2017 \\
\text { Malaysia }\end{array}$ & $\begin{array}{l}\text { SF-36 Quality of life } \\
\text { Clinical data } \\
\text { - } \text { Weight } \\
\text { - } \text { BMI } \\
\text { - } \text { Syist/hip } \\
\text { - } \text { admission } \\
\text { Diastolic on } \\
\text { - } \text { admission } \\
\text { - } \text { admist rate on } \\
\text { Ljection fraction } \\
\text { Lifestyle } \\
\text { - Smoking }\end{array}$ & $\begin{array}{ll}\text { - } & \text { Before } \\
\text { intervention } \\
\text { - } 6 \text { months } \\
\text { - } 12 \text { months }\end{array}$ & $\begin{array}{l}\text { Quality of life } \\
\text { - Pharmaceutical care intervention } \\
\text { significantly improved quality of life } \\
\text { - The Modified CRP group } \\
\text { consistently showed better QoL, was } \\
\text { more highly motivated and benefitted } \\
\text { most from the CRP }\end{array}$ \\
\hline $\begin{array}{l}\text { Meng et al. } \\
2013 \\
\text { German }\end{array}$ & $\begin{array}{l}\text { Illness knowledge } \\
\text { Modified version of the } \\
\text { Godin Leisure -Time } \\
\text { Exercise Questionnaire } \\
\text { Healthy diet } \\
\text { A nine -item modified } \\
\text { version of the self - } \\
\text { report Food List } \\
\text { Medication adherence - } \\
\text { German version of the } \\
\text { Medication Adherence } \\
\text { Report Scale (MARS - } \\
\text { D) }\end{array}$ & $\begin{array}{ll}\text { - } & \text { Before } \\
\text { intervention } \\
\text { - } & \text { Before discharge } \\
\text { - } & 6 \text { months } \\
\text { - } & 12 \text { months after } \\
\text { discharge }\end{array}$ & $\begin{array}{l}\text { Illness knowledge } \\
\text { - There is significant difference in } \\
\text { illness knowledge between group. } \\
\text { Physical activity } \\
\text { - There is significant difference } \\
\text { between group } \\
\text { Healthy diet } \\
\text { - There is no significant difference } \\
\text { between group } \\
\text { Medication adherence } \\
\text { - There is no significant difference } \\
\text { between group }\end{array}$ \\
\hline
\end{tabular}




\begin{tabular}{|c|c|c|c|}
\hline $\begin{array}{l}\text { Harbman } \\
2014 \\
\text { Canada }\end{array}$ & $\begin{array}{l}\text { Outcomes/ goals } \\
\text { achievement } \\
\text { - } \quad \text { Smoking status } \\
\text { - } \quad \text { Systolic BP } \\
\text { - } \text { Diastolic BP } \\
\text { - } \quad \text { Lipid (LDL } \\
\text { cholesterol, } \\
\text { HDL } \\
\text { cholesterol, and } \\
\text { triglycerides) } \\
\text { - Involvement in } \\
\text { physical activity } \\
\text { - Attendance at } \\
\text { CRP } \\
\text { - Glycated } \\
\text { haemoglobin } \\
\text { Medication used }\end{array}$ & $\begin{array}{l}\text { - } \text { Before discharge } \\
\text { - } 1 \text { week } \\
\text { - } 2 \text { weeks } \\
\text { - } 6 \text { weeks } \\
\text { - } 3 \text { months after } \\
\text { discharge }\end{array}$ & $\begin{array}{l}\text { Target goals } \\
\text { - Significantly improved achievement } \\
\text { of the target goals (smoking } \\
\text { cessation, reduce blood pressure, } \\
\text { attendance at cardiac rehabilitation, } \\
\text { improve physical activity, achieving } \\
\text { a glycated haemoglobin }<7 \% \text { in } \\
\text { those with diabetes, triglyceride } \\
\text { levels, statin use at follow-up) }\end{array}$ \\
\hline $\begin{array}{l}\text { Lau-Walker, } \\
\text { Landy, \& } \\
\text { Murrells } \\
2016\end{array}$ & $\begin{array}{l}\text { The Hospital Anxiety } \\
\text { and Depression Scale } \\
\text { The Dartmouth COOP } \\
\text { Quality of Life } \\
\text { Questionnaire }\end{array}$ & $\begin{array}{l}\text { - } \quad \text { Before discharge } \\
\text { - } 3 \text { months after } \\
\text { discharge }\end{array}$ & $\begin{array}{l}\text { Emotional state } \\
\text { - There is no significant difference } \\
\text { after } 3 \text { months in the emotio nal state } \\
\text { of the participants } \\
\text { Quality of life }\end{array}$ \\
\hline $\begin{array}{l}\text { United } \\
\text { Kingdom }\end{array}$ & $\begin{array}{l}\text { The total activity } \\
\text { measure (TAM) } \\
\text { The Cardiac Diet Self - } \\
\text { Efficacy Instrument } \\
\text { Cardiac Exercise Self - } \\
\text { Efficacy Instrument } \\
\text { The Brief Illness } \\
\text { Perception } \\
\text { Questionnaire (BIPQ) }\end{array}$ & & $\begin{array}{l}\text { - There is significant difference after } 3 \\
\text { months on 'General Health' } \\
\text { subscales but no difference in other } 2 \\
\text { subscales } \\
\text { Physical exercise } \\
\text { - There is no significant difference } \\
\text { after } 3 \text { months } \\
\text { Self-efficacy } \\
\text { - There is no significant difference } \\
\text { after } 3 \text { months } \\
\text { Illness belief } \\
\text { - There is significant difference after } 3 \\
\text { months on 'Understanding' subscales } \\
\text { but no difference in other } 9 \text { subscales }\end{array}$ \\
\hline
\end{tabular}

Behavioral and lifestyle changes

The behavioral changes that measured in the studies were the main components of the healthy lifestyle that proven can help to prevent the recurrence of the disease. The behavior that mainly included was smoking habit, physical activity, exercise habit, and dietary intake. It showed that the participants significantly changed in the smoking habit and physical activity but not in the dietary intake.

\section{Physiological risk factors}

The physiological measures were mainly the cardiac risk factors as also suggested by the Clinical Practice Guideline Primary and Secondary prevention of CVD 
by Malaysian Ministry of Health (Ministry of Health, 2017). The physiological risk factors measured to investigate the effect of the early educational intervention include blood pressure, body mass index, serum lipid, waist circumference and glycated haemoglobin $<7 \%$. These physiological risk factors were significantly improved before and after intervention as well as between comparison groups.

\section{Self-efficacy}

According to (Bandura, 1998), all behavioural changes are mediated by self-efficacy, where a person with low self-efficacy is less likely to have confidence to carry out a new health behaviour, or try to change an embedded behaviour. Thus, self-efficacy should be measured together with the behavioural change. There were two studies that measure the Cardiac Self Efficacy Scale (CSES) where both were randomized control trial study (Vibulchai et al., 2016; Weibel et al., 2014) and both studies reported significant difference in the selfefficacy between intervention and control group.

\section{Other outcomes}

The other outcomes measured in the studies included that showed significant difference were quality of life and illness knowledge. Whereas medication adherence, anxiety and depression and emotional state of the participant showed no significant difference after the intervention.

\section{DISCUSSION}

The purpose of the study reviewed was to describe the early educational intervention offered to the patients with ACS and the outcomes from the intervention. The method of the educational intervention played an important role in determining the success of the program, especially measuring the behavioural changes of the participants. All studies included in this review were mainly inpatient educational intervention, where the intervention initiated during hospitalization and most of the interventions were held in the hospital itself.

Only one study by (Vibulchai, 2016) had incorporated the in-hospital education with the telephone counselling sessions that based on the self-efficacy enhancement after the participants discharged from the hospital. The intervention from the study showed significantly higher self-efficacy and functional status four weeks after discharged, compared to the normal cardiac rehabilitation program. (Eakin, et al., 2007) had systematically reviewed twenty-six studies that used telephone intervention for physical activity and dietary behaviour change agreed that telephone call can be used as a primary intervention in giving education to the patients. However, (Vibulchai, 2016) only measure the outcomes as early as four weeks after discharge. However, there is a need to measure a long-term effect of the early educational intervention on cardiac selfefficacy whether the self-efficacy will further build over time or not.

The duration of the follow up can affect the outcomes measured from the intervention. Weibel (2014) had the shortest time where the cardiac-self efficacy and anxiety and depression were measured at baseline before the inpatient education given in the ward, and prior to discharge. Although the study showed a significantly better score of self-efficacy in the ability to control the symptoms in the intervention group, it is as expected as the duration between the intervention and the endpoint was very short. However, this study is a pilot RCT study and the author did realize the need of long-term follow up. Besides, this study only measures the anxiety and depression of the patient, not the change of the behavior.

The significant improvement in behavioural measure marked the effectiveness of the educational intervention delivered to the participants. Physical activity is one of the behavioural measures that mostly tested and showed significant changes before and after the intervention as well as between comparison groups. Smoking cessation is one of the behavioural changes that easily measured and showed significant change before and after the intervention as well as between comparison groups. However, both of the behavioural changes measured are self-reported by the participants. Thus, measuring the behavioural change itself in a study may or may not manifest the effectiveness of the intervention.

The addition of the physiological measures in the study to support the behavioural change that mainly measured by self-reporting is somehow recommended. The physiological measures were mainly the cardiac risk factors as also suggested by the Clinical Practice Guideline Primary and Secondary prevention of CVD by Malaysian Ministry of Health (Ministry of Health, 2017) that include blood pressure (systolic and diastolic), body mass index, serum lipid, waist circumference and glycated haemoglobin $<7 \%$. 


\section{RECOMMENDATIONS}

From the literatures examined, there is a need to investigate the effectiveness of the early inpatient educational intervention on self-efficacy in view of build the confidence to improve their healthy behaviour. The literature also showed that early educational intervention produces significant effect on physical activity. Thus, as a future recommendation, it is needed to test whether the significant effect have any relationship with the self-efficacy of the participant. Furthermore, it is also recommended to incorporate the measure of the physiological values if the physical activity is self-reported by the participants.

\section{CONCLUSION}

Acute coronary syndrome is a disease that must be treated and prevented from recurrence. Cardiac rehabilitation is a secondary prevention strategy that helps the patients to recover from the cardiac events. Even though studies have shown the benefit of cardiac rehabilitation, there are still some barriers that make the cardiac rehabilitation underutilized and even in some countries not well established. Alternative approaches need to be considered for cardiac rehabilitation, where appropriate programs for patients that suits with the patient needs especially while the patients are still in the hospital. The early educational intervention that inculcates the self-efficacy enhancement should be considered to guide the patients to manage themselves at home and lead a healthy lifestyle to prevent the recurrence of the disease. The telephone call strategy for follow up as well as for educations is important to maintain the continuity of the program and monitoring of the progress during cardiac rehabilitation.

\section{REFERENCES}

Anchah, L., Hassali, M. A., Lim, M. S. H., Ibrahim, M. I. M., Sim, K. H. \& Ong, T. K. (2017). Health related quality of life assessment in acute coronary syndrome patients: the effectiveness of early phase I cardiac rehabilitation. Health and Quality of Life Outcomes, 15(1), pp: 10.

Bandura, A. (1998). Self-efficacy. Encyclopedia of Human Behavior, 4(1994), pp: 1-65.

Beauchamp, A., Worcester, M., Ng, A., Murphy, B., Tatoulis, J., Grigg, L., Newman, R., Goble, A.
(2013). Attendance at cardiac rehabilitation is associated with lower all-cause mortality after 14 years of follow-up. Heart Br. Card Soc. 99 (9), pp: 620-625.

Chernomordik, F., Sabbag, A., Tzur, B., Kopel, E., Goldkorn, R., Matetzky, S., Goldenberg, I., Shlomo, N., Klempfner, R. (2017). Cardiac rehabilitation following an acute coronary syndrome: Trends in referral, predictors and mortality outcome in a multicenter national registry between years 2006-2013: Report from the Working Group on Cardiac Rehabilitation, the Israeli Heart Societ. European Journal of Preventive Cardiology, 24(2), pp: 123-132.

Dunlay, S. M., Pack, Q. R., Thomas, R. J., Killian, J. M., \& Roger, V. L. (2014). Participation in Cardiac Rehabilitation, Readmissions, and Death After Acute Myocardial Infarction. The American Journal of Medicine, 127(6), pp: 538-546

Eakin, E. G., Lawler, S. P., Vandelanotte, C., \& Owen, N. (2007). Telephone interventions for physical activity and dietary behavior change: A systematic review. American Journal of Preventive Medicine, 32(5), pp: 419-434.

Engen-Verheul, H., De-Vries, H., Kemps, H., Kraaijenhagen, R., De Keizer, N., Peek, N. (2013). Cardiac rehabilitation uptake and its determinants in the Netherlands, European Journal of Preventive Cardiology. 20 (2), pp:349-356.

Galve, E., Alegría, E., Cordero, A., Fácila, L., Fernández de Bobadilla, Lluís-Ganella, C. et al. (2014). Update in cardiology: vascular risk and cardiac rehabilitation, Revista Española de Cardiología. 67 (3), pp: 203-210

Harbman, P. (2014). The development and testing of a nurse practitioner secondary prevention intervention for patients after acute myocardial infarction: A prospective cohort study. International Journal of Nursing Studies, 51(12), pp: 1542-1556.

Irmak, Z., \& Fesci, H. (2010). Effects of nursemanaged secondary prevention program on lifestyle and risk factors of patients who had experienced myocardial infarction. Applied Nursing Research, 23(3), pp:147-152.

Lemstra, M.E., Alsabbagh, W., Rajakumar, R.J., Rogers, M.R., Blackburn, D. (2013). Neighbourhood 
income and cardiac rehabilitation access as determinants of nonattendance and noncompletion. Canadian Journal of Cardiology 29 (12), pp: 1599-1603.

Mampuya, W. M. (2012). Cardiac rehabilitation past, present and future: an overview. Cardiovascular Diagnosis and Therapy, 2(1), pp:38-49.

Meng, K., Seekatz, B., Haug, G., Mosler, G., Schwaab, B., Worringen, U., \& Faller, H. (2014). Evaluation of a standardized patient education program for inpatient cardiac rehabilitation: Impact on illness knowledge and self-management behaviors up to 1 year. Health Education Research, 29(2), pp: 235-246.

Ministry of Health. (2017). Clinical Practice Guidelines on Primary \& Secondary Prevention of Cardiovascular Disease 2017. Ministry of Health Malaysia. Putrajaya. Retrieve from: https:// www.malaysianheart.org/? $\mathrm{p}=\operatorname{cpg} \& \mathrm{a}=1171$

National Cardiovascular Disease Database (NCVD). (2013). Annual Report of the Acute Coronary Syndrome (ACS) Registry 2011-2013. National Heart Association of Malaysia (NHAM) and the Ministry of Health Malaysia. Malaysia. Retrieve from: https://www.crc.gov.my/wp-content/ uploads/documents/report/report NCVD_Acute Coronary_Syndrome_Registry_09_10.pdf
Oldridge, N., Höfer, S. \& Mcgee, H. (2012). The HeartQoL : Part II . Validation of a new core healthrelated quality of life questionnaire for patients with ischemic heart disease ., European Journal of Preventive Cardiology 21(1), pp: 98-106.

Turk-Adawi, K., Oldridge, N.B., Tarima, S.S., Stason, W.B., Shepard, D.S. (2014). Cardiac rehabilitation enrollment among referred patients: patient and organizational factors, Journal of Cardiopulmonary Rehabilitation and Prevention 34 (2), pp:114-122.

Uysal, H., \& Özcan, Ş. (2012). The effect of individual training and counselling programme for patients with myocardial infarction over patients' quality of life. International Journal of Nursing Practice, 18(5), pp: 445-453.

Vibulchai, N., Thanasilp, S., \& Preechawong, S. (2016). Randomized controlled trial of a selfefficacy enhancement program for the cardiac rehabilitation of Thai patients with myocardial infarction. Nursing \& Health Sciences, 18(2), pp: 188-195.

Weibel, L., Massarotto, P., Hediger, H., \& Mahrerimhof, R. (2014). Early education and counselling of patients with acute coronary syndrome. A pilot study for a randomized controlled trial. European Journal of Cardiovascular Nursing. 21(1) pp:98106 